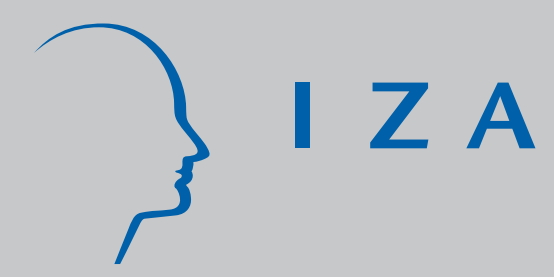

IZA DP No. 2302

Accident Risk, Gender, Family Status and Occupational Choice in the UK

Suzanne Grazier

Peter J. Sloane

September 2006 


\title{
Accident Risk, Gender, Family Status and Occupational Choice in the UK
}

\author{
Suzanne Grazier \\ WELMERC, University of Wales at Swansea \\ Peter J. Sloane \\ WELMERC, University of Wales at Swansea \\ and IZA Bonn
}

Discussion Paper No. 2302

September 2006

\author{
IZA \\ P.O. Box 7240 \\ 53072 Bonn \\ Germany \\ Phone: +49-228-3894-0 \\ Fax: +49-228-3894-180 \\ Email: iza@iza.org
}

\begin{abstract}
Any opinions expressed here are those of the author(s) and not those of the institute. Research disseminated by IZA may include views on policy, but the institute itself takes no institutional policy positions.
\end{abstract}

The Institute for the Study of Labor (IZA) in Bonn is a local and virtual international research center and a place of communication between science, politics and business. IZA is an independent nonprofit company supported by Deutsche Post World Net. The center is associated with the University of Bonn and offers a stimulating research environment through its research networks, research support, and visitors and doctoral programs. IZA engages in (i) original and internationally competitive research in all fields of labor economics, (ii) development of policy concepts, and (iii) dissemination of research results and concepts to the interested public.

IZA Discussion Papers often represent preliminary work and are circulated to encourage discussion. Citation of such a paper should account for its provisional character. A revised version may be available directly from the author. 
IZA Discussion Paper No. 2302

September 2006

\section{ABSTRACT}

\section{Accident Risk, Gender, Family Status and Occupational Choice in the UK}

Many studies show that women are more risk averse than men. In this paper, following DeLeire and Levy (2004) for the US, we use family structure as a proxy for the degree of risk aversion to test the proposition that those with strong aversion to risk will make occupational choices biased towards safer jobs. In line with DeLeire and Levy we find that women are more risk averse than men and those married with children are more risk averse than those without. However, the effect on the degree of gender segregation is much smaller than for the US.

JEL Classification: J0, J2, K2

Keywords: accident risk, gender segregation, family status, occupational choice

Corresponding author:

Peter J. Sloane

WELMERC, School of Business and Economics

Swansea University, Richard Price Building

Singleton Park

Swansea SA2 8PP

United Kingdom

E-mail: p.j.sloane@swansea.ac.uk 


\section{INTRODUCTION}

There is now a substantial literature suggesting that women are more risk averse than men. Thus, Datta Gupta et al. (2005) show using experimental data, that when given a choice between the riskier option of a tournament and payment by piece rates men choose a tournament significantly more often than women. Brown and Taylor (2005) show that men are more likely than women to invest in risky assets such as shares and unit trusts. Ekeland et al. (2005), using psychometric data from a large population based cohort of Finns in 1996, show that men are less risk averse than women and this makes them significantly more likely to become self employed than women. Reed and Dahlquist (1994) find for the US that women are more likely to be employed in safer jobs than men and Dohmen et al. (2005) likewise for Germany. The British Social Attitudes Survey (2001) found evidence that British workers regard safe working conditions as an important job characteristic, with 83 per cent citing little risk of injury or damage to health as either very or fairly important to them; men however, were less likely than women to report this as an important job characteristic. Further significant differences in attitudes towards health and safety between men and women were reported, with men significantly less likely to say that not enough attention was paid to protecting workers from risk of injury in Britain. Men were also significantly less likely to wear protective clothing at work than women when required to do so.

DeLeire and Levy (2004) use family structure as a proxy for the willingness to work in occupations with a relatively high accident rate, to test the proposition that workers with strong risk aversion will tend to make occupational choices 
which sort them into safer jobs. They find that single mothers and single fathers are the most risk averse groups and that risk of death across occupations can explain no less than one quarter of occupational gender segregation in the USA. In this paper we attempt to replicate the DeLeire and Levy findings using UK data.

Firms and workers are heterogeneous. The former will differ in their ability to provide safety at work and workers will vary in their willingness to accept a hazardous job. If we assume that firms attempt to maximise profits and workers to maximise utility, an equilibrium outcome will result in which the most risk averse workers will be matched with firms which find it relatively easy to provide a safe working environment and the least risk averse workers will sort into riskier jobs for which they will receive a compensating wage differential. Turning specifically to gender, the persistence of gender occupational segregation is well established, but its causes disputed. In terms of labour demand men and women might possess different skill endowments which cause employers to favour one gender over the other for specific jobs, or employers may simply discriminate. On the supply side men and women may differ in their preferences for certain types of job, so that segregation is simply the result of individual choice and it is this which DeLeire and Levy focus upon. As preferences for risk cannot be measured directly they use gender and family structure as proxies. The latter will not correlate so obviously with discrimination and thus isolate preferences. They hypothesise that single parents will be most risk averse because children are then totally dependent on a single parent and that the presence of children will make both 
men and women more risk averse than childless couples. In turn married women will be more risk averse than married men, because they generally take the more significant role in child-rearing. Their results confirm that single parents are the group most averse to risk and, regardless of family structure, that men are less risk averse than women. Hence "single parents choose jobs with lower risk of death than their married or childless counterparts” (p. 940) and overall their results offer "strong empirical support for the hypothesis that workers sort into jobs on the basis of their preferences” (p.946). The question we address is whether similar outcomes are present in the UK, though it should be noted that the incidence of fatalities and injuries in the UK is amongst the lowest in Europe and substantially lower than in the $\mathrm{US}^{1}$.

\section{METHODOLOGY}

We use the same approach as DeLeire and Levy (2004) to test empirically the impact of risk on occupational choice. Following Greene (2003), it is assumed that individuals choose an occupation consistent with a random utility model. Individual i's choice of occupation j (from J occupations) results in utility $\mathrm{U}_{\mathrm{ij}}$, as illustrated by equation 1 .

$$
U_{i j}=\beta \mathrm{Z}_{\mathrm{ij}}^{\prime}+\varepsilon_{i j}
$$

The exogenous variable $\mathrm{Z}_{\mathrm{ij}}$ can be divided into variables that depend only on the individual $\left(\mathrm{W}_{\mathrm{i}}\right)$ such as education, and those that vary across the occupation choices $\left(\mathrm{X}_{\mathrm{j}}\right)$ such as risk of death. Hence:

$$
Z_{i j}=\left[W_{i}+X_{j}\right]
$$

\footnotetext{
${ }^{1}$ See Health and Safety Executive (2000) for a discussion of this.
} 
If the individual chooses occupation $\mathrm{j}$, we assume that the resulting utility $\mathrm{U}_{\mathrm{ij}}$ is the maximum among the $\mathrm{J}$ utilities. The probability that choice $\mathrm{j}$ is made can therefore be illustrated by equation 3 :

$$
\operatorname{Prob}\left(U_{i j}>U_{i k}\right) \quad \text { for all other } k \neq j
$$

If the disturbances are independent and identically distributed with an extreme value distribution, then McFadden (1973) shows that the observed occupation choice of individual i $\left(\mathrm{Y}_{\mathrm{i}}\right)$ can be denoted by the conditional logit model, as shown by equation 4:

$$
\operatorname{Prob}\left(Y_{i}=j\right)=\frac{e^{\beta z_{i j}^{\prime}}}{\sum_{j=1}^{J} e^{\beta z_{i j}^{\prime}}}
$$

Substituting in $\mathrm{W}_{\mathrm{i}}$ and $\mathrm{X}_{\mathrm{j}}$ for $\mathrm{Z}_{\mathrm{ij}}$ we derive the following:

$$
\operatorname{Prob}\left(Y_{i}=j\right)=\frac{e^{\beta^{\prime} x_{j}} e^{\alpha_{i}^{\prime} w_{i}}}{\sum_{j=1}^{J} e^{\beta^{\prime} x_{j}} e^{\alpha_{i}^{\prime} w_{i}}}
$$

Terms that do not vary across alternatives $\left(\mathrm{W}_{\mathrm{i}}\right)$ and are specific to the individual fall out of the probability and we are unable to estimate the effect of individual characteristics upon occupational choice, which are invariant to the choice. However, we can estimate $\beta$ and therefore the effect that occupational characteristics have upon occupational choice, as in McFadden's (1973) fixed effects model.

The conditional logit model assumes the error terms follow independently and identically an extreme value distribution. This independence of irrelevant alternatives (IIA) assumption should be tested, utilising a specification test (Hausman and McFadden, 1984). It is argued that if the omission of a choice 
does not significantly alter parameter values the assumption holds and choices are independent from irrelevant alternatives. Two models must be estimated; the first, denoted by subscript $f$, the model with a full set of choices, and the second, denoted by subscript $r$, the model with restricted choice (omitting a possible occupational choice from the model). The resultant parameter estimates $(\beta)$ and covariance matrices $(\Omega)$ are recorded and the test statistic, which follows a chi-square distribution calculated as in equation 6 below

$$
\chi^{2}=\left(\beta_{r}-\beta_{f}\right)^{\prime}\left(\Omega_{r}-\Omega_{f}\right)^{-1}\left(\beta_{r}-\beta_{f}\right)
$$

If the null hypothesis cannot be rejected, alternative choices are irrelevant and the IIA assumption is valid.

\section{DATA}

Three data sets are used in the estimation: the Labour Force Survey (LFS) for data on employment, Health and Safety Executive (HSE) data on fatal and major injuries, and the Skills Survey for data on occupational characteristics.

DeLeire and Levy restrict their analysis to full-time workers on the grounds that part-time workers will allocate some time to household production, for which risk data are not available. We prefer to include part-time workers in our analysis as we would expect family status to be an important determinant of whether an individual works full-time or part-time and to exclude parttimers would result in a disproportionate elimination of parents from the analysis. Further, individuals can change from full-time to part-time status 
and vice versa over time. To enable comparison, however, the estimation was also carried out for full-time workers only, though results are not reported here.

DeLeire and Levy also restrict their analysis to workers aged from 25 to 34 on the grounds that current risk measures are inaccurate for older workers, who have accumulated occupation-specific knowledge. However, since current risk rates reflect the presence of older workers, there is a danger of estimation bias if older workers are left out of the analysis and for this reason we prefer to leave them in. Again for comparison purposes, we have also performed the estimation for 25 to 34 year olds only, though again the results are not reported $^{2}$.

\section{$\underline{\text { Accident and Employment Data }}$}

Data on occupational risk of fatal and non-fatal injury are collected by the HSE under the Reporting of Injuries, Diseases and Dangerous Occurrences Regulations (RIDDOR) 1995, which requires employers to report fatalities and specific non-fatal injuries at work to the HSE. Risk rates are typically calculated by industry or occupation and then matched into another data set. Ideally, one would want to estimate risk for each occupation-by-industry cell, but most occupations have zero recorded deaths, so this is not practicable (see Sandy et al. 2001 for a discussion of this). To ensure sufficient observations, we take average numbers of fatalities and major injuries from RIDDOR

\footnotetext{
${ }^{2}$ Self-employed workers are excluded from the estimation. RIDDOR does not require injuries to the self-employed that occurred at their own premises to be reported, and so their inclusion would bias the results.
} 
reports for 2002/3, 2003/4 and 2004/5 measured according to occupation (SOC 2000).

The LFS September-November 2004 is used to provide data on the number of workers employed in each occupation. With a large sample size that includes detailed information on occupation, marital status and number of children, this enables workers to be divided according to family group.

Initial observation reveals that in 2004 men constituted 50.8 per cent of fulltime and part-time employment combined, but were responsible for 96.2 per cent of fatal injuries and 73.6 per cent of major injuries at work between 20022005. Thus, men are much more likely to have an accident at work than women.

Using the data on employment from the LFS, death and major injury numbers are converted into rates according to 2 digit SOC 2000, giving a total of 25 occupations. Non gender-specific rates are calculated because of issues of inaccuracy and measurement error which would result from estimating female risk rates in occupations in which few women are found ${ }^{3}$. A death rate per 100 full-time and part-time workers and a major injury rate per 100 full-time and part-time workers are calculated for each of the 25 occupations. In addition, the fraction of female workers employed in each occupation is also calculated. The appropriate death and major injury rates are then assigned to

\footnotetext{
${ }^{3}$ By using the average risk in an occupation, we are overstating the risk for women and understating it for men. Female risk measures however, would fail to reflect the true risk of fatality in occupations where there are few female employees. Male-specific measures are derived and compared to the overall risk rates, with the order of risky occupations remaining the same.
} 
each worker in the LFS sample according to their 2 digit occupation code.

Table 1 reports the rates for each occupation in order of the highest death rate.

This reveals that 4 of the 25 occupations have a zero death rate compared to only 2 out of 44 in the DeLeire and Levy study.

Table 1: Occupational Death and Major Injury Rates per 100 Workers and Fraction of Female Workers (Full-Time and Part-Time Workers of all Ages)

\begin{tabular}{|l|r|r|r|}
\hline & $\begin{array}{l}\text { Death Rate } \\
\text { per 100 } \\
\text { Workers }\end{array}$ & $\begin{array}{l}\text { Major Injury } \\
\text { Rate per 100 } \\
\text { Workers }\end{array}$ & $\begin{array}{l}\text { Fraction } \\
\text { of Female } \\
\text { Workers }\end{array}$ \\
\hline 51 skilled agricultural trades & 0.02124 & 0.33791 & 0.07447 \\
\hline 53 skilled construction and building trades & 0.00668 & 0.53282 & 0.01089 \\
\hline $\begin{array}{l}\text { 91 elementary trades, plant and storage } \\
\text { related occupations }\end{array}$ & 0.00353 & 0.36870 & 0.16283 \\
\hline $\begin{array}{l}\text { 82 transport and mobile machine drivers } \\
\text { and operatives }\end{array}$ & 0.00322 & 0.34417 & 0.03385 \\
\hline 81 process plant and machine operatives & 0.00311 & 0.45278 & 0.24108 \\
\hline 52 skilled metal and electrical trades & 0.00182 & 0.21324 & 0.01422 \\
\hline $\begin{array}{l}\text { 12 managers and proprietors in agriculture } \\
\text { and services }\end{array}$ & 0.00165 & 0.12957 & 0.42615 \\
\hline 33 protective service occupations & 0.00116 & 0.31025 & 0.18525 \\
\hline 21 science and technology professionals & 0.00078 & 0.09053 & 0.15265 \\
\hline $\begin{array}{l}\text { 92 elementary admin \& service } \\
\text { occupations }\end{array}$ & 0.00057 & 0.14363 & 0.58145 \\
\hline $\begin{array}{l}\text { 31 science and technology associate } \\
\text { professionals }\end{array}$ & 0.00043 & 0.08451 & 0.22731 \\
\hline $\begin{array}{l}\text { 62 leisure and other personal service } \\
\text { occupations }\end{array}$ & 0.00032 & 0.08024 & 0.62992 \\
\hline 54 textiles, printing and other skilled trades & 0.00028 & 0.11618 & 0.33590 \\
\hline 11 corporate managers & 0.00025 & 0.03337 & 0.32465 \\
\hline 34 culture, media and sports occupations & 0.00021 & 0.04401 & 0.47954 \\
\hline 61 caring personal service occupations & 0.00011 & 0.10700 & 0.90478 \\
\hline 24 business \& public service professionals & 0.00010 & 0.02658 & 0.41663 \\
\hline 71 sales occupations & 0.00009 & 0.09201 & 0.70318 \\
\hline 42 secretarial and related occupations & 0.00004 & 0.02455 & 0.97283 \\
\hline 41 administrative occupations & 0.00003 & 0.02971 & 0.74717 \\
\hline $\begin{array}{l}\text { 35 business and public service associate } \\
\text { professionals }\end{array}$ & 0.00003 & 0.01805 & 0.47347 \\
\hline 72 customer service occupations & 0 & 0.02977 & 0.49102 \\
\hline $\begin{array}{l}\text { 32 health \& social welfare associate } \\
\text { professionals }\end{array}$ & 0 & 0.05946 & 0.68455 \\
\hline 23 teaching and research professionals & & & 0.83046 \\
\hline 22 health professionals & & & \\
\hline
\end{tabular}


The three occupations with the greatest death rate are Skilled Agricultural Trades (where 7.4 per cent of workers are female), Skilled Construction Trades and Building Trades (where 1.1 per cent of workers are female) and Elementary Trades, Plant and Storage Related Occupations (where 16.3 per cent of workers are female). The occupations with the least risk are Health Professionals (49.1 per cent female), Teaching and Research Professionals (64.7 per cent female), Health and Social Welfare Associate Professionals (83 per cent female) and Customer Service Occupations (68.5 per cent female). Note that the UK death rate is lower than that calculated by DeLeire and Levy for the US. Their greatest death rate is calculated as 0.0872 per 100 workers compared to 0.0212 per 100 workers here. However, our UK rates include part-time workers and so we would expect the risk to be slightly lower. Also, the overall fatality rate at work is slightly greater in the US compared to the $\mathrm{UK}^{4}$.

Table 2: Correlation between Log Death, Log Major Injury and Fraction Female

\begin{tabular}{|l|l|r|}
\hline & \multicolumn{1}{|c|}{$\begin{array}{c}\text { Fraction of } \\
\text { Female Workers }\end{array}$} \\
\hline Log Death & $\begin{array}{l}\text { Pearson } \\
\text { Correlation }\end{array}$ & $-0.792^{* *}$ \\
\hline Log Major Injury & $\begin{array}{l}\text { Pearson } \\
\text { Correlation }\end{array}$ & $-0.648^{* * *}$ \\
\hline
\end{tabular}

$* * *$ Correlation is significant at the 0.01 level (2-tailed).

** Correlation is significant at the 0.05 level (2-tailed).

The correlation between the death rate per 100 workers for each occupation and the fraction of female workers employed in each occupation is reported in Table 2 and shown in Figure 1. The correlation is significantly negative,

\footnotetext{
${ }^{4}$ See Health and Safety Executive (2000) for more detail on this.
} 
indicating that occupations with the highest death rates are associated with fewer female employees.

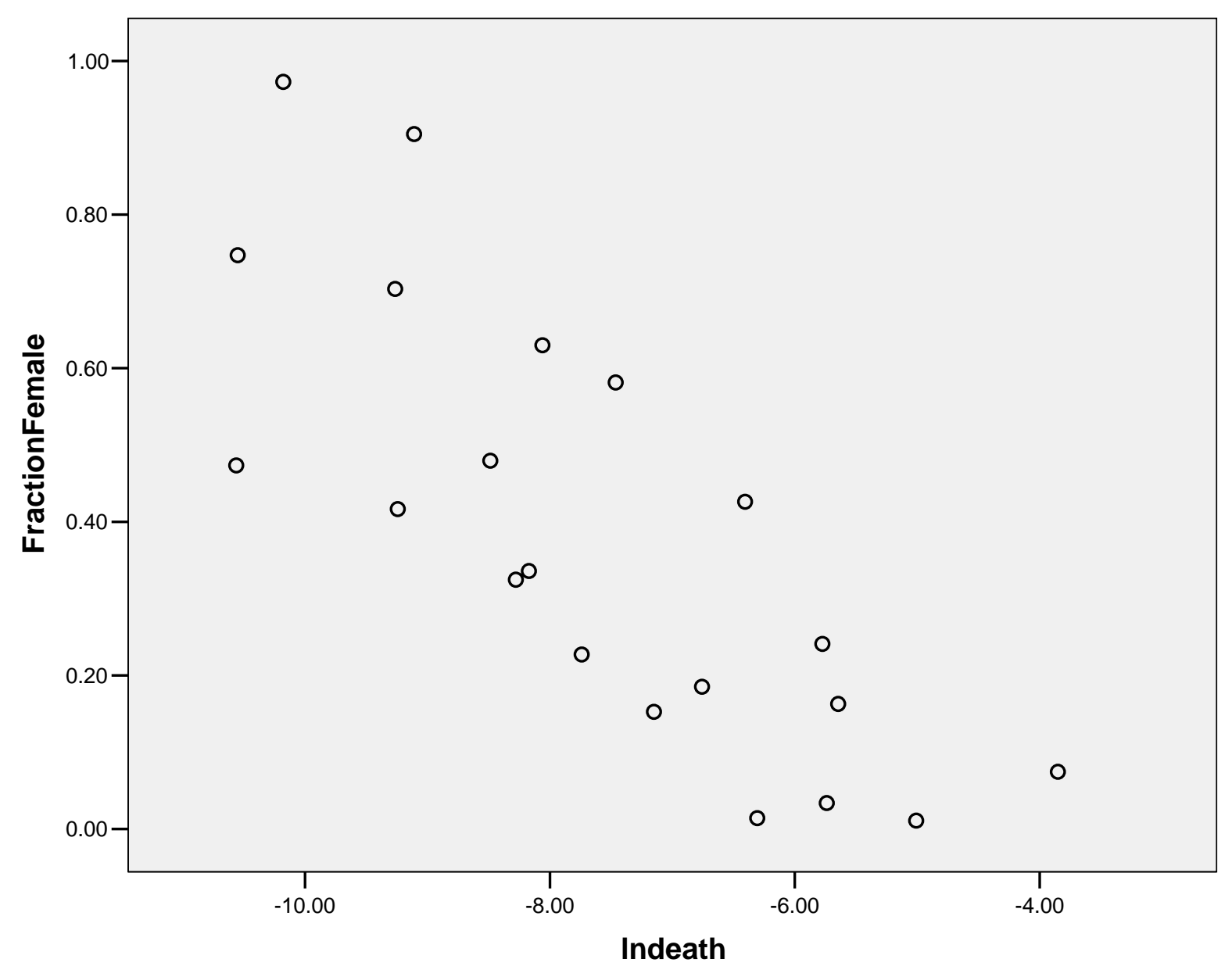

Figure 1: Correlation between Log Death and Fraction of Female Workers

Table 2 and Figure 2 show the correlation between the major injury rate and the fraction of female workers is also significantly negative. As expected, the correlation is slightly lower than the correlation between the death rate and the fraction of female workers which may be due to a stronger aversion to risk of fatality.

In order to check the accuracy of the occupational risk estimates, Table 3 shows there is a significant positive correlation between the death rate and major injury rate. This confirms that occupations with a high death rate are also likely to have a high major 
injury rate. The fact that the correlation is strong but not perfect means the effect of both an occupations death and major injury rate can be estimated separately.

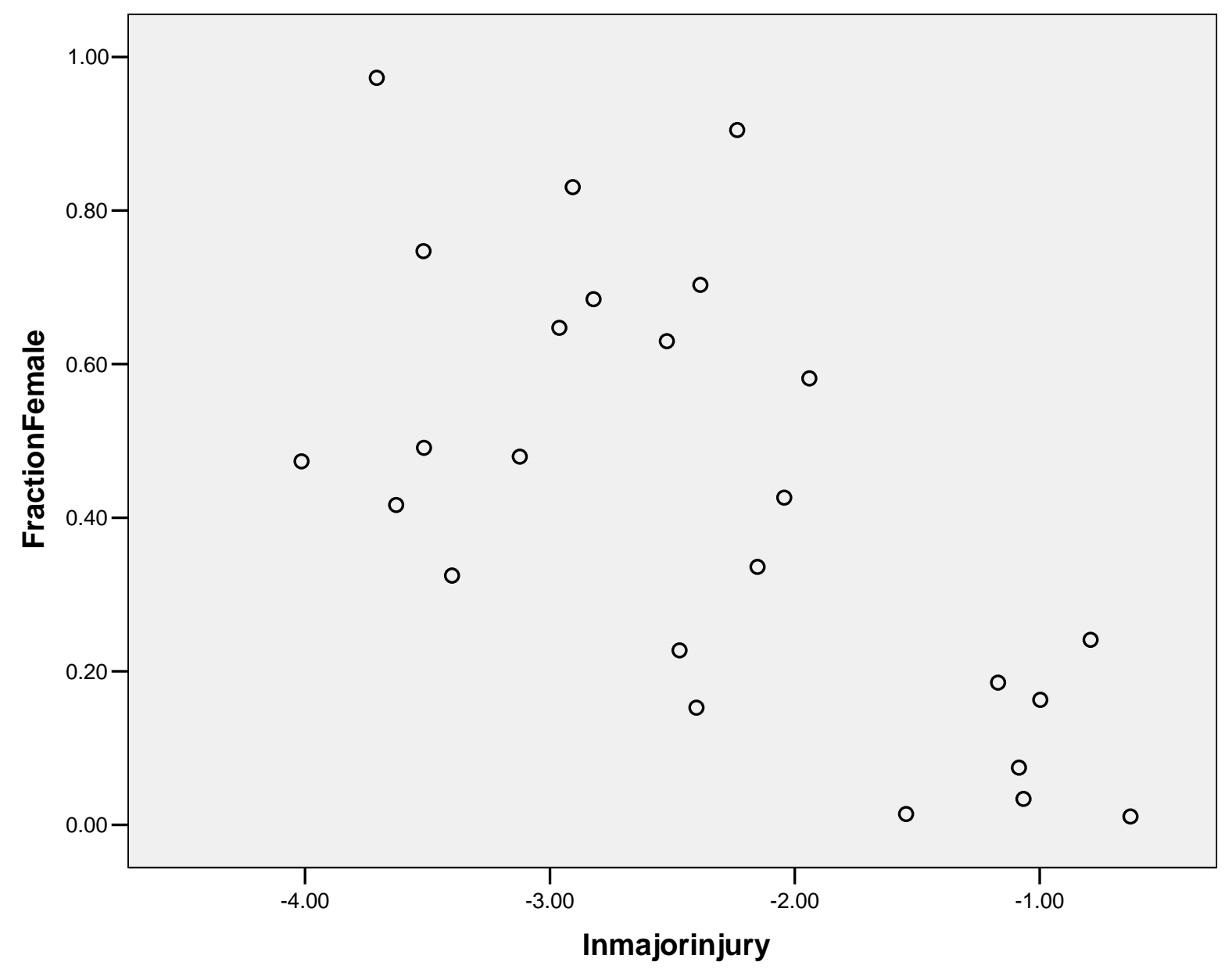

Figure 2: Correlation between Log Major Injury and Fraction of Female Workers

Table 3: Correlation between Log Death and Log Major Injury

\begin{tabular}{|l|l|r|}
\hline & & Log Major Injury \\
\hline Log Death & $\begin{array}{l}\text { Pearson } \\
\text { Correlation }\end{array}$ & $0.894^{* * *}$ \\
\hline
\end{tabular}

*** Correlation is significant at the 0.01 level (2-tailed).

\section{Occupational Characteristics}

In order to estimate the effect risk of death and injury has upon occupation choice, other characteristics associated with each occupation must be 
controlled for. This is particularly important when comparing what influences occupation choice between different groups of workers, as specific groups may have particular preferences. For example, men may be more likely to work in more physically demanding occupations and women in occupations requiring more caring skills. ${ }^{5}$ Thus, it is necessary to control for occupational attributes in addition to the risk of death and injury rates.

Occupational attribute variables were created using the Skills Survey 2001. Employed individuals aged 20-64 in GB were surveyed, with a sample size of 4470 being achieved. Workers were asked how important a particular skill or attribute was to their work. Table 4 lists the variables to be used in the estimation, and their definitions.

Table 4: Occupational Attributes Variables

\begin{tabular}{|l|l|}
\hline Variable & Occupational Attribute \\
\hline STRENGTH & Physical strength \\
\hline STAMINA & Physical stamina \\
\hline HANDS & Skill or accuracy in using hands or fingers \\
\hline TOOLS & Knowledge of how to use or operate tools \\
\hline WRITELG & Writing long documents \\
\hline CALCA & Adding, subtracting, multiplying or dividing numbers \\
\hline STATS & Calculations using advanced mathematical or statistical procedures \\
\hline CARING & Counselling, advising or caring of customers or clients \\
\hline SPECIAL & Specialist knowledge or understanding \\
\hline ANALYSE & Analysing complex problems in depth \\
\hline MYTIME & Organising own time \\
\hline USEPC & Using a PC or other computerised equipment \\
\hline SPEECH & Making speeches or presentations \\
\hline PERSUADE & Using persuasion \\
\hline LISTEN & Listening to customers or clients \\
\hline MOTIVATE & Motivating staff \\
\hline FUTURE & Making decisions that affect the future of the company \\
\hline PERCENTC & Percentage of workers covered by union terms and conditions \\
\hline
\end{tabular}

Variables created from the Skills Survey 2001

\footnotetext{
${ }^{5}$ See for example Thewlis et al. (2004)
} 
Each variable takes a value from 0-4, with 4 defined as essential to the work, and 0 defined as not at all important. The mean of each attribute for each occupation is then calculated using 2 digit SOC 2000. The means are reported in Appendix 1. In addition, the percentage covered by union terms and conditions has been calculated for each occupation using the LFS.

All skills variable means are as would be expected. In terms of the physical variables for instance, low means for strength, stamina, hands and tools are calculated for Corporate Managers (11), Administrative Occupations (41), and Business and Public Service Associate Professionals (35), indicating these skills are relatively unimportant for these occupations. In contrast, they are very important for working in Skilled Agricultural Trades (51), Skilled Metal and Electrical Trades (52), and Skilled Construction and Building Trades (53).

Considering the correlations between all skills variables, death and major injury variables, and the fraction female in each occupation, death and major injury are positively and significantly associated with strength, stamina, hands and tools. As would be expected, occupations that require physical skills are associated with a higher death and major injury rate. In contrast, usepc and persuade are negatively associated with both death and major injury rates. Fraction female is significantly positively correlated with caring and listen skills, indicating that women are more likely to work in occupations that require these attributes.

Standardised scores (z statistics) were calculated for each of the occupational attribute variables to check the significance of their variation between the 25 
occupations. These results suggest that there is no significant variation between occupations for only five of these variables, the implications of which are considered later.

\section{ESTIMATION}

\section{$\underline{\text { Family Variables }}$}

The finding that risk has a greater negative impact upon occupational choice for women could be due to direct discrimination by employers, which forces women to work in safer jobs regardless of their preferences, or indirect discrimination through, for instance, schools portraying safe occupations as stereotypical womens' jobs. As it is less likely that this type of discrimination occurs according to family structure, the inclusion of family circumstances in the estimations allows us to determine whether workers sort into occupations according to preferences for risk.

Separate samples of workers are created according to gender, marital status, and whether a worker has children, using data from the LFS. Table 5 describes the groups created, and the fraction of the whole sample to which each contributes. The groups with the greatest number in the sample are single men with no children (13.5 per cent), and married men with no children (12.7 per cent). By contrast, separated, divorced or widowed men with children make up only 1 per cent of the sample, and separated, divorced or widowed women with children make up only 3 per cent. Correlations are calculated between each of the family variables and both the log of death and log of major injury, to compare the effect of the risk of an occupation upon 
occupational choice between family groups. Table 6 reports the correlation coefficients.

Table 5: Family Groups and Fraction of Total Sample (Full-Time and Part-Time Workers of all Ages)

\begin{tabular}{|l|l|}
\hline & Fraction of Sample \\
\hline Single Men with no Children & 0.135 \\
\hline Single Women with no Children & 0.105 \\
\hline Single Men with Children & 0.051 \\
\hline Single Women with Children & 0.061 \\
\hline Married Men no Children & 0.127 \\
\hline Married Women no Children & 0.125 \\
\hline Married Men with Children & 0.150 \\
\hline Married Women with Children & 0.127 \\
\hline Separated, Divorced, Widowed Men no Children & 0.034 \\
\hline Separated, Divorced, Widowed Women no Children & 0.042 \\
\hline Separated, Divorced, Widowed Men with Children & 0.010 \\
\hline Separated, Divorced, Widowed Women with Children & 0.030 \\
\hline
\end{tabular}

Note: Cohabiting unmarried couples are classified as single

In line with results of the previous correlations between the risk variables and the fraction of female workers, a negative correlation is calculated for all female groups, and a positive correlation for all male groups. This emphasises the association of all men with relatively riskier jobs than women. Within the family groups, among women single females are the most averse to risk. However, contrary to expectations, the correlation is not stronger for single females with children. Nor for all female groups combined does having children result in a greater negative correlation. For men the results are more in line with what would be expected: having children reduces the correlation coefficient for all three groups except for single men where the correlation coefficients are very similar. 
Table 6: Correlations between Family Group and Log Death and Log Major Injury

\begin{tabular}{|l|l|l|l|l|l|l|}
\hline & $\begin{array}{l}\text { Single men no } \\
\text { children }\end{array}$ & $\begin{array}{l}\text { Single men } \\
\text { with children }\end{array}$ & $\begin{array}{l}\text { Married men no } \\
\text { children }\end{array}$ & $\begin{array}{l}\text { Married men } \\
\text { with children }\end{array}$ & $\begin{array}{l}\text { SDW men no } \\
\text { children }\end{array}$ & $\begin{array}{l}\text { SDW men with } \\
\text { children }\end{array}$ \\
\hline $\begin{array}{l}\text { Log Death } \\
\text { Pearson Correlation }\end{array}$ & $0.694^{* * *}$ & $0.705^{* * *}$ & $0.676^{* * *}$ & $0.565^{* * *}$ & $0.812^{* * *}$ & $0.619^{* * *}$ \\
\hline $\begin{array}{l}\text { Log Major Injury } \\
\text { Pearson Correlation }\end{array}$ & $0.538^{* * *}$ & $0.748^{* * *}$ & $0.538^{* *}$ & $0.412^{* *}$ & $0.728^{* * *}$ & $0.690^{* * *}$ \\
\hline
\end{tabular}

\begin{tabular}{|l|l|l|l|l|l|l|}
\hline & $\begin{array}{l}\text { Single women } \\
\text { no children }\end{array}$ & $\begin{array}{l}\text { Single women } \\
\text { with children }\end{array}$ & $\begin{array}{l}\text { Married women } \\
\text { no children }\end{array}$ & $\begin{array}{l}\text { Married women } \\
\text { with children }\end{array}$ & $\begin{array}{l}\text { SDW women } \\
\text { no children }\end{array}$ & $\begin{array}{l}\text { SDW women } \\
\text { with children }\end{array}$ \\
\hline $\begin{array}{l}\text { Log Death } \\
\text { Pearson Correlation }\end{array}$ & $-0.802 * * *$ & $-0.444 * *$ & $-0.745^{* * *}$ & $-0.789 * * *$ & $-0.750^{* * *}$ & $-0.624 * * *$ \\
\hline $\begin{array}{l}\text { Log Major Injury } \\
\text { Pearson Correlation }\end{array}$ & $-0.754^{* * *}$ & -0.186 & $-0.632 * * *$ & $-0.638^{* * *}$ & $-0.575^{* * *}$ & $-0.390^{*}$ \\
\hline
\end{tabular}




\section{Conditional Logit Results}

The conditional logit model is utilised as only one choice can be made among a number of occupations. As we are interested in how the effect of the explanatory variables upon occupational choice varies between specific groups of workers, the model is estimated separately by gender and family structure (the groups listed in Table 5). Table 7 presents the estimated coefficients and odds ratios for the death and major injury variables from the fourteen estimations.

For reasons of space we do not give the results for occupational attributes here, but overall, as expected, strength has a greater positive effect upon occupational choice for men than for women. Women are more likely to choose an occupation that requires hands skills, with the coefficient significantly negative for men (-1.877) and significantly positive for women (3.634). A further significant difference in the estimated coefficients between the male and female samples concerns the variable listen, with the effect upon occupational choice significantly negative for men, but significantly positive for women. 
Table 7: Conditional Logit Death rate and Major Injury rate Estimates by Family Group (Full-Time and Part-Time Workers of all Ages)

\begin{tabular}{|c|c|c|c|c|c|c|c|}
\hline & MEN & $\begin{array}{l}\text { Single men no } \\
\text { children }\end{array}$ & $\begin{array}{l}\text { Single men with } \\
\text { children }\end{array}$ & $\begin{array}{l}\text { Married men no } \\
\text { children }\end{array}$ & $\begin{array}{l}\text { Married men with } \\
\text { children }\end{array}$ & $\begin{array}{l}\text { SDW men no } \\
\text { children }\end{array}$ & $\begin{array}{l}\text { SDW men with } \\
\text { children }\end{array}$ \\
\hline $\begin{array}{l}\text { No. of obs } \\
\text { Log Likelihood }\end{array}$ & $\begin{array}{l}24807 \\
-73043.254 \\
\end{array}$ & $\begin{array}{l}6087 \\
-18203.998 \\
\end{array}$ & $\begin{array}{l}3002 \\
-7175.237 \\
\end{array}$ & $\begin{array}{l}6483 \\
-18792.526 \\
\end{array}$ & $\begin{array}{l}7519 \\
-21251.124 \\
\end{array}$ & $\begin{array}{l}1720 \\
-5017.205 \\
\end{array}$ & $\begin{array}{l}492 \\
-1407.472 \\
\end{array}$ \\
\hline \multicolumn{8}{|l|}{ Death } \\
\hline $\begin{array}{l}\text { Coefficient } \\
\text { Standard error } \\
\end{array}$ & $\begin{array}{l}-240.397 * * * \\
(6.625)\end{array}$ & $\begin{array}{l}-122.352 * * * \\
(12.497) \\
\end{array}$ & $\begin{array}{l}157.626 * * * \\
(45.125)\end{array}$ & $\begin{array}{l}-261.458 * * * \\
(12.695) \\
\end{array}$ & $\begin{array}{l}-289.240 * * * \\
(11.685)\end{array}$ & $\begin{array}{l}-244.581^{* * * *} \\
(23.873)\end{array}$ & $\begin{array}{l}-348.701 * * * \\
(54.497)\end{array}$ \\
\hline $\begin{array}{l}\text { Odds Ratio } \\
\text { Standard error }\end{array}$ & $\begin{array}{l}4.0 e-105 \\
(2.5 e-104) \\
\end{array}$ & $\begin{array}{l}7.30 e-54 \\
(9.12 e-53) \\
\end{array}$ & $\begin{array}{l}3.50 \mathrm{e}-69 \\
(1.58 \mathrm{e}-67) \\
\end{array}$ & $\begin{array}{l}2.8 \mathrm{e}-114 \\
(3.6 \mathrm{e}-113) \\
\end{array}$ & $\begin{array}{l}2.4 \mathrm{e}-126 \\
(2.8 \mathrm{e}-125)\end{array}$ & $\begin{array}{l}6.0 \mathrm{e}-107 \\
(1.4 \mathrm{e}-105) \\
\end{array}$ & $\begin{array}{l}.6 e-152 \\
(2.0 \mathrm{e}-150) \\
\end{array}$ \\
\hline \multicolumn{8}{|l|}{ Major Injury } \\
\hline $\begin{array}{l}\text { Coefficient } \\
\text { Standard error } \\
\end{array}$ & $\begin{array}{l}3.140 * * * \\
(0.147) \\
\end{array}$ & $\begin{array}{l}0.844^{* * *} \\
(0.286)\end{array}$ & $\begin{array}{l}-1.515 \\
(1.040)\end{array}$ & $\begin{array}{l}3.490 * * * \\
(0.289) \\
\end{array}$ & $\begin{array}{l}4.685 * * * \\
(0.274) \\
\end{array}$ & $\begin{array}{l}4.099 * * * \\
(0.558) \\
\end{array}$ & $\begin{array}{l}5.526 * * * \\
(1.067) \\
\end{array}$ \\
\hline $\begin{array}{l}\text { Odds Ratio } \\
\text { Standard error } \\
\end{array}$ & $\begin{array}{l}23.099 \\
(3.399) \\
\end{array}$ & $\begin{array}{l}2.326 \\
(0.666) \\
\end{array}$ & $\begin{array}{l}0.220 \\
(0.229)\end{array}$ & $\begin{array}{l}32.792 \\
(9.461) \\
\end{array}$ & $\begin{array}{l}108.269 \\
(29.620)\end{array}$ & $\begin{array}{l}60.262 \\
(33.597) \\
\end{array}$ & $\begin{array}{l}193.199 \\
(206.145) \\
\end{array}$ \\
\hline
\end{tabular}

\begin{tabular}{|c|c|c|c|c|c|c|c|}
\hline & WOMEN & $\begin{array}{l}\text { Single women no } \\
\text { children }\end{array}$ & $\begin{array}{l}\text { Single women } \\
\text { with children }\end{array}$ & $\begin{array}{l}\text { Married women } \\
\text { no children }\end{array}$ & $\begin{array}{l}\text { Married women with } \\
\text { children }\end{array}$ & $\begin{array}{l}\text { SDW women no } \\
\text { children }\end{array}$ & $\begin{array}{l}\text { SDW women with } \\
\text { children }\end{array}$ \\
\hline $\begin{array}{l}\text { No. of Obs } \\
\text { Log Likelihood }\end{array}$ & $\begin{array}{l}25334 \\
-68108.29\end{array}$ & $\begin{array}{l}5011 \\
-13931.753\end{array}$ & $\begin{array}{l}3002 \\
-7181.167\end{array}$ & $\begin{array}{l}6660 \\
-17692.679\end{array}$ & $\begin{array}{l}6738 \\
-17797.665\end{array}$ & $\begin{array}{l}2225 \\
-5974.783\end{array}$ & $\begin{array}{l}1601 \\
-4205.277\end{array}$ \\
\hline \multicolumn{8}{|l|}{ Death } \\
\hline $\begin{array}{l}\text { Coefficient } \\
\text { Standard error }\end{array}$ & $\begin{array}{l}-267.126^{* * *} \\
(21.516)\end{array}$ & $\begin{array}{l}-273.065^{* * *} \\
(56.463)\end{array}$ & $\begin{array}{l}-140.464 * * * \\
(44.322)\end{array}$ & $\begin{array}{l}-209.294^{* * *} \\
(27.894)\end{array}$ & $\begin{array}{l}-1434.851^{* * *} \\
(185.548)\end{array}$ & $\begin{array}{l}-1464.118^{* * *} \\
(281.985)\end{array}$ & $\begin{array}{l}-175.294^{* * *} \\
(44.176)\end{array}$ \\
\hline $\begin{array}{l}\text { Odds Ratio } \\
\text { Standard error }\end{array}$ & $\begin{array}{l}9.7 e-117 \\
(2.1 \mathrm{e}-115)\end{array}$ & $\begin{array}{l}2.6 \mathrm{e}-119 \\
(1.4 \mathrm{e}-117)\end{array}$ & $\begin{array}{l}9.94 \mathrm{e}-62 \\
(4.40 \mathrm{e}-60)\end{array}$ & $\begin{array}{l}1.27 e-91 \\
(3.55 e-90) \\
\end{array}$ & $\begin{array}{l}0 \\
(0)\end{array}$ & $\begin{array}{l}0 \\
(0)\end{array}$ & $\begin{array}{l}7.42 \mathrm{e}-77 \\
(3.28 \mathrm{e}-75)\end{array}$ \\
\hline \multicolumn{8}{|l|}{ Major Injury } \\
\hline $\begin{array}{l}\text { Coefficient } \\
\text { Standard error }\end{array}$ & $\begin{array}{l}-0.309 \\
(0.389)\end{array}$ & $\begin{array}{l}0.508 \\
(0.907)\end{array}$ & $\begin{array}{l}-2.136^{* *} \\
(1.044)\end{array}$ & $\begin{array}{l}-1.122 \\
(0.725)\end{array}$ & $\begin{array}{l}13.145^{* * *} \\
(2.263)\end{array}$ & $\begin{array}{l}14.714^{* * * *} \\
(3.422)\end{array}$ & $\begin{array}{l}-1.423 \\
(1.341)\end{array}$ \\
\hline $\begin{array}{l}\text { Odds Ratio } \\
\text { Standard error }\end{array}$ & $\begin{array}{l}0.734 \\
(0.286)\end{array}$ & $\begin{array}{l}1.662 \\
(1.507)\end{array}$ & $\begin{array}{l}0.118 \\
(0.123)\end{array}$ & $\begin{array}{l}0.326 \\
(0.236)\end{array}$ & $\begin{array}{l}51.13574 \\
(11.57440)\end{array}$ & $\begin{array}{c}24.55323 \\
(84.02732)\end{array}$ & $\begin{array}{l}0.2408933 \\
(0.3230932)\end{array}$ \\
\hline
\end{tabular}

Data: LFS 2004, Skills Survey 2001, HSE 2002/03-2004/05. Other variables included in estimation: Strength, Stamina, Hands, Tools, Writelg, Calca, Stats, Caring, Special,

Analyse, Mytime, Usepc, Speech, Persuade, Listen, Motivate, Future, and Percentc. 
In terms of the risk variables, overall women are found to be more risk averse than men. For men, death has a coefficient of -240.397 , whilst for women a coefficient of -267.126 is found, both of which are significant at the 1 per cent level. This shows that death has a greater negative effect upon women's occupational choice compared to men's occupational choice. For men, a significant positive coefficient is found for the major injury variable ${ }^{6}$ For women, the coefficient is negative although insignificant.

Results for the two risk variables are also reported as odds ratios, taking a value between zero and infinity. A ratio of 1 indicates the risk variable makes no difference in predicting occupational choice, and a value of 0 indicates it makes a large difference. An odds ratio less than 1 indicates risk has a negative effect upon occupational choice. Odds ratios for the death variable reported in Table 7 are negative and very close to zero, indicating fatal risk has a large negative effect upon occupational choice.

To confirm whether it is differences in preferences for risk that contribute to occupation sorting and not discrimination, it is necessary to consider the individual family groups for each gender. In terms of the variable death in the male samples, for each of the three groups having children is always associated with a greater negative coefficient as in DeLeire and Levy. The least risk averse group are single men with no children, with a significant coefficient of -122.352 estimated. Unlike DeLeire and Levy, married men are

\footnotetext{
${ }^{6}$ DeLeire and Levy find a positive coefficient for non fatal injury risk for all groups of men and women. They emphasise that such a result is not totally surprising given that a fatal injury variable is also included, and the two are correlated here with a significant correlation coefficient of 0.894 (see Table 3).
} 
more risk averse than single men as anticipated. To summarise, the presence of children increases male aversion to risky work, in line with expectations and the findings of DeLeire and Levy. For the UK male, being married also increase preferences for safer work.

For the female estimations, as expected married women with children are more averse to risky occupations than married women with no children. For single women with no children however, a greater negative coefficient on death is estimated than for single mothers. However, the coefficient for major injury in the single women with no children sample is positive and significant, whereas major injury is negative and significant for single mothers. Women with children appear to be averse to non-fatal injury in addition to fatal injury, unlike men, and this is likely to affect the magnitude of the coefficient on the variable death.

DeLeire and Levy find a positive coefficient for their non-fatal injury variable in all of their regressions. Major injury estimates are positive in most of the male sample regressions, with the exception of single men with children, for whom a negative, though insignificant, coefficient is found. For women, a negative coefficient is found for the all women sample, single women with children, married women with no children, and separated, divorced or widowed women with children. The coefficient is insignificant, however, in all of these samples except for single women with children, where it is significant at the 5 per cent level. As reported earlier, the death and major injury variables are collinear with a correlation coefficient of 0.894 , possibly explaining the positive sign when both variables are included in the model. 
Therefore, the estimation was repeated for each family group, first with just the death variable, and then with just the major injury variable. For reasons of space, results of these estimations are not reported.

The effect of excluding the major injury variable has little impact upon the estimated death coefficients and odds ratios. For men, groups with children are still the most averse to risk with greater negative coefficients estimated for death compared to childless groups. This is especially true for men with no partner. Single men with no children are found to be the least averse to risk. For women, those married with children and SDW with no children remain the most averse to risk.

Now consider the effect of excluding the death variable from the model. The majority of the estimations result in a negative coefficient for the major injury variable, confirming that positive estimates when death was included were due to collinearity. For men, single men with children have the greatest negative major injury coefficient followed by single men with no children. The major injury variable, however, remains either insignificant or positive for other male groups. The role of the major injury variable is relatively more important for female occupational choice compared to male occupational choice. For instance, for men overall a coefficient of -0.482 is estimated, compared to -5.942 for women, both of which are significant at the 1 per cent level. The major injury variable is negative and significant for all of the female regressions, indicating the risk of non-fatal injury is significant in determining occupational choice. For women, the greatest negative coefficient is estimated for married women with children, followed by married women 
with no children. For all groups, a larger negative coefficient is found for those with children compared to the childless equivalent of the groups.

Overall, the results indicate women are more averse to risk than men in terms of their occupational choice, with the risk of non-fatal injury more of a concern to women than to men. This could be due to women preferring safer work, or due to discrimination. However, the fact that within gender, risk has different effects upon occupational choice according to family structure in the expected way, suggests that preferences for risk do affect occupational choice in the UK.

To enable direct comparison with DeLeire and Levy, the estimations were repeated for a sample of full-time workers aged 25-34. Again, women were more risk averse than men, with the death rate variable coefficient estimated as -231.800 for women and -167.438 for men. For the male family groups, the ordering of aversion to risk in occupational choice is the same for this sample as to the sample of full-time and part-time workers of all ages. For all groups of men, having children increases the aversion to risk, as before. For women however, there are differences in the results. Having children does not increase aversion to risk, whereas before married women with children were more averse to risk than married women with no children. This could be due to expectations of the future for this relatively younger sample of workers. Married women with no children may expect to have children in the future, and so make their occupational decision on the assumption that this will be the case. This could also be true for single women with no children. 
Following the results of the standardised scores in which the variation of the occupational attributes variables between occupations was considered, the conditional logit model is re-estimated excluding the five variables with no significant variation (writelong, stats, special, usepc and future). Excluding these five explanatory variables has no effect upon the pattern of results between groups for the death variable. The only difference in the results concerns the major injury variable. Whereas in the previous estimation with all variables included the major injury variable was only significantly negative for single women with children, when the five variables are excluded, major injury is significantly negative for all of the female estimations. Furthermore, the major injury coefficient follows the pattern expected, being greater for all groups with children. Excluding these variables therefore, although not affecting the overall conclusions reached before, does impact upon the major injury estimates.

\section{$\underline{\text { Independence of Irrelevant Alternatives (IIA) }}$}

As discussed in the Methodology section, the conditional logit model assumes the error terms are independent across irrelevant alternatives. In this case, this requires the choice between two occupations to be independent from the choice between other occupations. If the IIA assumption does not hold, this could lead to inconsistent estimates. Following Hausman and McFadden (1984) the test statistic denoted by equation 6, which follows a chi-square distribution is calculated. This test statistic is compared to the relevant value from the $\chi^{2}$ distribution. If the test statistic is significantly greater, given by the 
probability value ( $p$ value), then the estimates are significantly different and the null hypothesis, and therefore the IIA assumption, is rejected.

DeLeire and Levy conduct Hausman and McFadden tests for the validity of the IIA assumption, although they do not report the full results. They do however, note that "we reject that the coefficients are the same, which is equivalent in this case to rejecting the IIA property of the conditional logit model” (p.942). The choice of one occupation over another is therefore influenced by the existence of other occupations. DeLeire and Levy do not discuss the implications of this result for their estimates, possibly on the grounds that the failure of the model to satisfy the IIA assumption does not affect their main conclusion: that preferences for risk vary by gender and family structure and influence occupational choice.

To test whether the IIA assumption holds in our model, Hausman and McFadden tests were conducted separately for men and women. In total, 25 tests were conducted, omitting each occupation in turn. Most of the tests resulted in large test statistics, which were significantly greater than the critical $\chi^{2}$ value. In these cases (where p value is equal to 0.0000 ) the null hypothesis that differences in estimates are not significant is rejected, and the IIA assumption does not hold. It does hold however, for females when occupation 53 is omitted.

DeLeire and Levy also find their results fail the IIA test, but still report their estimates as evidence that family groups in the US sort into occupations 
according to risk. As an alternative to the conditional logit model, a nested logit model can be used if the IIA test fails. To confirm the reliability of the estimates given that our model fails the IIA assumption, a nested logit was estimated. The 25 occupations were grouped into manual and non-manual occupations $^{7}$ and the model re-estimated by family group ${ }^{8}$. The pattern of results remained the same as in the conditional logit model: women were more averse to death in occupational choice, with marriage and the presence of children also increasing aversion to risk. This confirms the fact that failure to satisfy the IIA assumption in the conditional logit model does not affect the pattern of results.

\section{Further Tests}

Results from the conditional logit estimations above suggest that workers have different preferences for risky work according to gender and family structure, and this in turn leads to a degree of occupational sorting. However, to be sure that the estimation results are confirming this hypothesis, it is necessary to consider a number of other possibilities that may be causing or biasing the results.

\section{(i) Demographic Characteristics}

It is important to ensure that the observed results between family groups are not due to the correlation between family structure and other demographics.

\footnotetext{
${ }^{7}$ In SOC 2000 codes, manual occupations are 51,52, 53, 54, 61, 62, 81, 82, 91, 92 and non-manual occupations are 11, 12, 21, 22, 23, 24, 31, 32, 33, 34, 35, 41, 42, 71, 72.

${ }^{8}$ The nested logit model was estimated with fewer variables than the conditional logit model because of problems with collinearity, with variables having only two values, one for manual occupation and the other for non-manual occupation. Major injury was one of the variables dropped from the model.
} 
For example, education could be correlated with family group, which in turn could determine aversion to risk and consequently occupational choice. Therefore, following DeLeire and Levy, we need to ensure that the pattern of results is due to family group and not due to education, race and union status. In order to do this three sets of dummy variables were created using the LFS data for education, race and union membership. We find, as DeLeire and Levy, that single men and women with children are much less likely to have a degree, compared to other groups, their highest qualification tending to be a GCSE.

Three sets of models are estimated, again using the conditional logit model, separately for each of the family groups, including all variables as before except for death. Death is interacted with the four education dummies in the first model, and these four interaction variables are added to the estimation. The same method is applied to a model for race and a model for union status.

Results indicate that more educated individuals place a greater negative weight on risk of death when making their occupation choice. For all family groups, having a degree results in the greatest risk aversion, whilst having no qualifications results in the least aversion to risk. However, the pattern of aversion remains the same as before between family groups. For example, taking the variable death*degree, a greater negative coefficient is observed for women (-1099.708) compared to men (-880.226). For men, having children still results in a greater negative coefficient for all education interaction variables, with married men with children the most averse to risk. DeLeire 
and Levy originally found for men that single parents were the most averse to risk, but with the inclusion of education dummies married men with children became the most averse to risk. DeLeire and Levy conclude that "the single dad result is being driven by the pattern among male high school graduates and high school drop-outs” (p.940). Here, however, married men with children were always the most averse to risky work amongst males, and continue to be so when education dummies are included. For race, the death*white variable again shows women to be the most averse to risk. For men, having children increases the aversion, with married men with children, and separated, divorced or widowed men with children most averse. For women, as before, separated, divorced or widowed women with no children and married women with children are the most averse. The same pattern of results is shown for the union status model.

Overall, estimating the model with demographic interaction variables makes no difference to the pattern of results. In terms of occupational choice in the UK, family structure and gender are driving the aversion to risk in the occupational decision, rather than the differences in other demographics between the groups.

\section{(ii) Occupations Requiring Absences from Home}

DeLeire and Levy consider the possibility that risky occupations may also require absences from home, raising the possibility that certain groups of workers may avoid them for this reason, rather than risk aversion per se. That is, fatal risk could be correlated with absences from home. They re-estimate 
the model dropping occupations most likely to involve frequent absences from home: motor vehicle operators, other transportation, farm workers and forestry and fishing, but find no change in the pattern of results when these occupations are omitted.

To repeat this analysis, we consider occupations in the UK that are most likely to require absences from home. We use data from the Skills Survey 2001, which asks respondents to state where their job requires them to work in the main: at home, at a fixed workplace, at a variety of places or on the move.

This analysis reveals that as expected, the majority of occupations involve working mainly at a fixed workplace. Transport and Mobile Machine Drivers and Operatives (82) tend to work on the move, (63 per cent of respondents) with no other occupation coming close to this in terms of working on the move. There are occupations, however, that have a high percentage of respondents saying they work in a variety of places and on the move; for example, in Skilled Agricultural Trades (51) 48 per cent work in a variety of places. However, for this occupation, working in a variety of places is most likely to be defined as working within the local vicinity. Skilled Agricultural workers are unlikely to work great distances from home on a regular basis that require overnight stays. This occupation is, therefore, unlikely to be avoided because of a dislike for work-related absences from home. In Skilled Construction and Building Trades (53), 77 per cent work in a variety of places and here this may deter certain family groups (especially parents) from choosing this occupation. Accordingly we re-estimated the model, omitting the Transport (82) and Construction (53) occupations that involve the most 
work away from home. Overall, the results show that women remain more averse to risky work than men and for men, having children continues to increase aversion to risky work. In addition, negative coefficients are now found for the major injury variable in all models. Married men with children have the largest significant negative coefficient for major injury compared to the other male groups. For women, married women with children remain the most averse to risk.

Overall, there are no major differences between this and the previous estimation, indicating that the omission of an absence from home variable is not driving the observed occupational choice pattern between family groups.

\section{OCCUPATIONAL GENDER SEGREGATION}

Having established that gender does appear to influence the effect that risk has upon occupational choice, we now address the question of how much this contributes to occupational gender segregation. Although we cannot distinguish whether the affect of risk upon occupation choice is due to different preferences between men and women or due to discrimination, it is still possible to determine how much less occupational gender segregation there would be if all jobs had equal risk rates.

The Duncan and Duncan (1955) Index of Dissimilarity is calculated as shown by equation 7 :

$$
\mathrm{D}=\frac{1}{2} \sum_{j=1}^{J}|f j-m j|
$$


where $\mathrm{mj}$ and $\mathrm{fj}$ refer to the predicted number of men and women in occupation j. As discussed, the fineness of the occupation classification affects the calculated risk rates and it will also affect the calculated index of segregation. DeLeire and Levy do not discuss how their occupational classification affects their results. Their model is estimated for 44 occupations. If there were fewer occupations, we might expect there to be less gender segregation, and if there were more a greater degree of segregation. Dolton and Kidd (1994) highlight this issue on the grounds that "the more detailed the occupation breakdown, the greater the contribution of gender differences in occupation distribution to the overall gender wage differential” (p.461). Therefore, we estimate three models and calculate three indices of segregation for 1 digit (9 occupations), 2 digit (25 occupations), and 3 digit (81 occupations) occupations according to the SOC 2000.

Explanatory variables derived from the Skills Survey used in the 2 digit occupation classification estimation are calculated for the 1 digit and 3 digit classifications. Death and major injury rates are also calculated for the new occupational classifications. Table 8 reports the highest death rate per 100 workers for all three classifications. As would be expected, the highest death rate is greater the finer the classification of occupations, though there is not much difference between the two and three digit classifications. Distinguishing finely between occupations highlights the very risky, and the very safe occupations.

Conditional logit models are run for all 3 occupation classifications, both excluding and including the two risk variables. Predicted values are obtained 
and the Duncan and Duncan Index according to equation 7 calculated. Table 8 reports the results.

Table 8: Index of Segregation Comparison by SOC 2000

\begin{tabular}{|l|l|l|l|}
\hline & 1 DIGIT & 2 DIGIT & 3 DIGIT \\
\hline $\begin{array}{l}\text { HIGHEST DEATH RATE } \\
\text { PER 100 WORKERS }\end{array}$ & 0.00366 & 0.0212380 & 0.0212384 \\
\hline $\begin{array}{l}\text { DUNCAN AND DUNCAN } \\
\text { INDEX INCLUDING RISK }\end{array}$ & $37.5 \%$ & $49 \%$ & $46.7 \%$ \\
\hline $\begin{array}{l}\text { DUNCAN AND DUNCAN } \\
\text { INDEX EXCLUDING RISK }\end{array}$ & $38.5 \%$ & $47.2 \%$ & $44.5 \%$ \\
\hline
\end{tabular}

For the two digit breakdown, the index of occupational segregation is calculated as 49 per cent when risk is included: 49 per cent of women would have to change jobs to achieve an identical distribution of men and women across occupations. When the model is re-estimated excluding the death and major injury variables, the index is calculated as 47.2 per cent: if all occupations had the same level of risk, 47 per cent of women would have to change jobs to achieve an identical distribution of men and women across occupations. Thus, occupational gender segregation would fall from 49 per cent to 47 per cent if risk were equal across all occupations. For the 1 digit classification, when risk is included occupational segregation is estimated as 37.5 per cent. This confirms the expectation that narrowing the occupational choice results in less gender segregation. Further, if risk were identical between men and women, 38.5 per cent of women would have to change jobs to achieve an identical distribution of men and women across occupations. Thus, risk plays no part in gender occupational segregation when occupations are classified by 1 digit SOC $2000^{9}$. Finally, the results using the 3 digit

\footnotetext{
9 There are problems with collinearity estimating the conditional logit model with just nine occupations. Restricting the number of occupations to nine means there is now little variation between
} 
breakdown show that occupational gender segregation falls from 46.7 per cent when risk is included, to 44.5 per cent when risk is identical between men and women.

Overall, occupational gender segregation increases when the breakdown of occupations increases from 9 to 25, but then falls slightly when the number of occupations is broken down even further to 81. Maximum segregation occurs, therefore, at a point between the 25 and 81 occupational breakdown, highlighting the importance of considering the breakdown of occupations when calculating this index.

The fall in the contribution of risk to occupational gender segregation is much less in all three of the occupational classifications than calculated for the US by DeLeire and Levy, who find that segregation would fall from 42.5 per cent to 24.2 per cent if risk were identical between men and women. However, there are generally higher risk rates for occupations in the US than in the UK. For instance, the most risky occupation found by DeLeire and Levy (Forestry and Fishing Occupations) has a death rate per 100 workers of 0.0872 , whereas the occupation with the highest death rate in the UK (Skilled Agricultural Trades) has a death rate of 0.0212 per 100 workers. We therefore expect risk to contribute less to occupation gender segregation in the UK.

In terms of the implications for the finding that differences in risk between occupations contributes to occupational gender segregation, Schaffner and

occupational characteristics. The model is estimated omitting the occupational characteristics from which there seems to be little variation in their value between the nine occupations. The variables used are Death, Majorinjury, Percentc, Strength, Stats, Caring, Writelg, and Hands. 
Kluve (2006) suggest that, if segregation explains part of the gender pay gap, then "the unequal distribution of occupational injury risk causes part of the gender wage differential” (p.3). Using German data they perform BlinderOaxaca decompositions to discover the extent to which differences in injury risks contributes to the gender wage gap. Their results indicate that controlling for differences in injury risk reduces the pay gap by up to 1 percentage point (p.17). They conclude by suggesting that differences in injury risk should be controlled for when estimating the gender wage differential.

\section{CONCLUSION}

As did DeLeire and Levy for the US we find that the death and major injury rate of an occupation has a significant impact upon occupational gender segregation in the UK. While this could be due either to differences in preferences for risk or to discrimination, or an element of both, the analysis further shows that within gender, occupational sorting occurs by family structure, thus ruling out the discrimination interpretation. Workers do, it seems, have different preferences for risky work. Furthermore, differences in fatal and non-fatal risk between occupations contribute to occupational gender segregation, with the degree of segregation falling slightly if there were no differences in risk rates between occupations. However, this is a much smaller effect than DeLeire and Levy found for the US and is consistent with the smaller accident risk across occupations in the UK, relative to the US. 


\section{$\underline{\text { REFERENCES }}$}

BROWN S. \& TAYLOR K. (2005) 'Wage Growth, Human Capital and Risk Preference: Evidence from the British Household Panel', Manchester School, Vol. 73, No. 6, pp.688-709

DATTA GUPTA N., POULSON A. \& VILLEVAL M. C. (2005) 'Male and Female Competitive Behaviour: Experimental Evidence’, IZA Discussion Paper No. 1883

DEE T. S. \& EVANS W N. (2001) 'Teens and Traffic Safety', in Jonathan Gruber (ed.), Risky Behaviour Among Youth, University of Chicago Press

DELEIRE T. \& LEVY H. (2004) 'Worker Sorting and the Risk of Death on the Job', Journal of Labor Economics, Vol. 22, No. 4, pp. 210-217

DOHMEN T., FALK A., HUFFMAN D., SUNDER U. M., SCHUPP J. \& WAGNER G G. (2005) 'Individual Risk Attitudes: New Evidence from a Large, Representative, Experimentally-Validated Survey’, IZA Discussion Paper No.1730

DOLTON, P J. \& KIDD M. P. (1994) 'Occupational Access and Wage Discrimination', Oxford Bulletin of Economics and Statistics, Vol. 56, No. 4, pp.457474.

DUNCAN O D. \& DUNCAN B. (1955) 'A Methodological Analysis of Segregation Indices’, American Sociological Review, Vol. 20, No. 2, pp.210-217

EKELAND J., JOHANSSON F., J. ÄRVELIN M. R. \& LICHTERMANN D. (2005) 'Self Employment and Risk Aversion: Evidence from Psychological Test Data', Labour Economics, Vol. 12, No. 5, pp.649-659

ENGLAND, P. (1982) 'The Failure of Human Capital Theory to Explain Occupational Sex Segregation', Journal of Human Resources, Vol.17, No.3, pp. 358370

ENGLAND, P. (1985) 'Occupational Segregation: Rejoinder to Polachek', Journal of Human Resources, Vol. 20. No.3, pp.441-443

GREENE, W. H. (2003) Econometric Analysis, Prentice Hall

HALEK, M. \& EISENHAUER, J. G. (2001) 'Demography of Risk Aversion', Journal of Risk and Insurance, Vol. 68, No.1, pp.1-24

HAUSMAN J. \& MCFADDEN D. (1984) 'A Specification Test for the Multinomial Logit Model’, Econometrica, Vol. 52, No. 5, pp.1219-1240

HEALTH AND SAFETY EXECUTIVE (2000) Statistics of Workplace Fatalities and Injuries in Great Britain: International Comparisons 2000, Health and Safety Executive 
MCFADDEN, D. (1973) 'Conditional Logit Analysis of Qualitative Choice Behaviour', in P. Zarembka (ed.), Frontiers in Econometrics, New York: Academic Press

MILLER L., NEATHEY F., POLLARD E. \& HILL D. (2004) 'Occupational Segregation, Gender Gaps and Skills Gaps’, Working Paper Series No. 15, Equal Opportunities Commission

POLACHEK, S. W. (1981) 'Occupational Self-Selection: A Human Capital Approach to Sex Differences in Occupational Structure', Review of Economics and Statistics, Vol. SEE, No. 1, pp.60-69

REED R. \& DAHLQUIST J. (1994) ‘Do Women Prefer Women’s Work?’, Applied Economics, Vol. 26, pp.1133-1144

SANDY R., ELLIOTT R. F., SIEBERT W S. \& WEI X. (2001) 'Measurement Error and the Effects of Unions on the Compensating Differentials for Fatal Workplace Risks’ Journal of Risk and Uncertainty, vol 23 No. 1, pp.33-56.

SCHAFFNER S. \& KLUVE J. (2006) 'Gender Wage Differentials and the Occupational Injury Risk: Evidence from Germany and the US', RWI, Essen, March 2006

THEWLIS M., MILLER L. \& NEATHEY F. (2004) 'Advancing Women in the Workplace: Statistical Analysis’, Working Paper Series No. 12, Equal Opportunities Commission

VISCUSI W K. \& HERSCH J. (2001) 'Cigarette Smokers as Job Risk Takers', Review of Economics and Statistics, Vol. 83, pp.269-280

VISCUSI W K. (2003) 'Racial Differences in Labor Market Values of a Statistical Life', The Journal of Risk and Uncertainty, Vol. 27, No. 3, pp.239-256 
APPENDIX 1: Occupational Characteristic Variable Means

\begin{tabular}{|c|c|c|c|c|c|c|c|c|c|c|c|c|c|c|c|c|c|c|}
\hline $\begin{array}{l}\text { SOC } \\
\text { code }\end{array}$ & Strength & Stamina & Hands & Tools & Writelg & Calc & Stat & Caring & Spec. & Anal. & $\begin{array}{l}\text { My } \\
\text { time }\end{array}$ & $\begin{array}{l}\text { Use } \\
\text { PC }\end{array}$ & Speech & Pers. & Listen & Motiv. & Future & PercentC \\
\hline 11 & 0.97 & 1.32 & 1.36 & 1.80 & 2.43 & 3.04 & 1.74 & 2.88 & 3.39 & 2.70 & 3.51 & 3.20 & 2.08 & 2.96 & 3.31 & 3.46 & 2.5 & 22.3 \\
\hline 12 & 1.78 & 2.15 & 2.33 & 2.31 & 1.61 & 2.96 & 1.37 & 3.02 & 3.06 & 2.47 & 3.36 & 2.10 & 1.34 & 2.76 & 3.16 & 3.42 & 2.56 & 18.9 \\
\hline 21 & 0.92 & 1.09 & 1.82 & 2.63 & 2.46 & 2.86 & 2.36 & 2.13 & 3.66 & 3.17 & 3.15 & 3.54 & 1.65 & 2.38 & 3.21 & 2.98 & 1.73 & 32.27 \\
\hline 22 & 0.77 & 1.57 & 2.91 & 2.84 & 2.66 & 2.29 & 1.83 & 3.67 & 3.93 & 3.37 & 3.30 & 2.80 & 2.16 & 2.83 & 3.40 & 3.39 & 2.47 & 58.81 \\
\hline 23 & 1.19 & 1.92 & 1.49 & 1.80 & 2.94 & 2.73 & 1.76 & 3.33 & 3.74 & 2.59 & 3.66 & 3.00 & 2.84 & 3.00 & 3.48 & 3.48 & 2.36 & 72.32 \\
\hline 24 & 0.49 & 1.08 & 0.96 & 1.41 & 2.95 & 2.67 & 1.65 & 3.10 & 3.59 & 3.16 & 3.61 & 3.15 & 2.41 & 2.97 & 3.33 & 3.32 & 2.13 & 35.35 \\
\hline 31 & 1.13 & 1.42 & 2.50 & 2.92 & 1.87 & 2.53 & 1.92 & 2.14 & 3.46 & 2.68 & 3.19 & 3.45 & 1.30 & 2.26 & 3.36 & 2.93 & 1.41 & 38.79 \\
\hline 32 & 1.80 & 2.08 & 2.40 & 2.62 & 2.26 & 2.41 & 1.08 & 3.78 & 3.64 & 2.56 & 3.46 & 2.21 & 1.60 & 2.53 & 3.53 & 3.36 & 1.54 & 63.13 \\
\hline 33 & 2.22 & 2.57 & 1.58 & 1.94 & 2.63 & 1.42 & 0.85 & 3.02 & 3.57 & 2.43 & 2.92 & 2.49 & 1.92 & 2.71 & 3.29 & 3.25 & 0.85 & 63.94 \\
\hline 34 & 1.52 & 2.02 & 2.62 & 2.62 & 2.12 & 1.81 & 0.97 & 2.21 & 3.54 & 2.53 & 3.27 & 3.05 & 3.25 & 3.50 & 2.33 & 3.04 & 1.87 & 26.4 \\
\hline 35 & 0.67 & 1.11 & 1.20 & 1.82 & 2.48 & 2.81 & 1.82 & 2.90 & 3.45 & 2.66 & 3.33 & 3.28 & 2.22 & 2.99 & 3.30 & 3.34 & 2.01 & 34.12 \\
\hline 41 & 0.86 & 0.98 & 1.76 & 1.91 & 1.84 & 2.81 & 1.50 & 2.36 & 2.81 & 1.93 & 3.00 & 3.56 & 0.82 & 1.82 & 3.15 & 3.05 & 1.15 & 42.97 \\
\hline 42 & 0.62 & 1.05 & 2.32 & 2.53 & 2.10 & 1.89 & 0.99 & 2.87 & 2.51 & 1.28 & 2.98 & 3.55 & 0.48 & 1.50 & 3.24 & 3.03 & 1.07 & 24.15 \\
\hline 51 & 3.54 & 3.22 & 3.18 & 3.45 & 1.86 & 1.59 & 1.00 & 2.11 & 3.18 & 2.04 & 3.10 & 0.93 & 0.90 & 1.57 & 2.93 & 3.33 & 2.00 & 18.57 \\
\hline 52 & 2.51 & 2.54 & 3.49 & 3.61 & 1.34 & 2.48 & 1.61 & 1.74 & 3.32 & 2.56 & 2.81 & 1.94 & 0.86 & 1.84 & 2.88 & 2.88 & 1.39 & 33.64 \\
\hline 53 & 3.03 & 2.93 & 3.58 & 3.55 & 1.18 & 2.50 & 1.28 & 2.26 & 3.14 & 2.03 & 2.97 & 0.90 & 0.58 & 1.70 & 2.63 & 3.12 & 1.72 & 20.39 \\
\hline 54 & 2.69 & 2.79 & 3.29 & 3.13 & 1.04 & 2.17 & 0.82 & 1.66 & 2.94 & 1.74 & 2.81 & 0.94 & 0.44 & 1.65 & 2.74 & 3.11 & 1.24 & 19.52 \\
\hline 61 & 2.30 & 2.46 & 2.07 & 1.96 & 1.51 & 1.68 & 0.95 & 3.43 & 2.91 & 1.72 & 2.72 & 1.19 & 0.93 & 2.11 & 3.28 & 2.97 & 1.33 & 32.91 \\
\hline 62 & 1.70 & 2.28 & 2.81 & 2.71 & 1.74 & 1.90 & 0.94 & 3.13 & 3.10 & 1.77 & 2.81 & 1.31 & 1.06 & 1.92 & 2.93 & 3.54 & 2.04 & 28.2 \\
\hline 71 & 1.96 & 2.04 & 2.09 & 2.10 & 1.09 & 2.60 & 1.07 & 2.93 & 2.71 & 1.49 & 2.46 & 2.36 & 0.80 & 1.90 & 2.96 & 3.17 & 1.44 & 17.92 \\
\hline 72 & 0.55 & 1.00 & 1.57 & 2.02 & 1.29 & 2.67 & 1.03 & 3.55 & 3.07 & 2.05 & 2.63 & 3.55 & 1.25 & 2.29 & 3.37 & 3.07 & 0.86 & 36.13 \\
\hline 81 & 2.36 & 2.54 & 3.09 & 3.29 & 1.07 & 2.24 & 1.26 & 1.34 & 2.72 & 1.83 & 2.33 & 1.66 & 0.72 & 1.73 & 2.88 & 3.26 & 1.24 & 36.76 \\
\hline 82 & 2.28 & 2.54 & 2.18 & 2.78 & 0.88 & 1.90 & 0.64 & 2.01 & 2.47 & 1.36 & 2.69 & 1.04 & 0.41 & 1.24 & 2.74 & 2.84 & 1.05 & 37.57 \\
\hline 91 & 2.92 & 2.81 & 2.76 & 2.88 & 1.08 & 2.11 & 0.96 & 1.38 & 2.33 & 1.38 & 2.51 & 1.33 & 0.61 & 1.48 & 2.66 & 3.07 & 1.44 & 28.37 \\
\hline 92 & 2.42 & 2.51 & 2.06 & 2.24 & 1.00 & 1.20 & 0.67 & 1.84 & 1.87 & 1.10 & 2.43 & 0.82 & 0.41 & 1.33 & 2.57 & 3.23 & 1.16 & 28.84 \\
\hline
\end{tabular}

Variable Abbreviations: Spec. = Special, Anal. =Analyse, Pers. =Persuade, Motiv. =Motivate

Created using the Skills Survey 2001 
